\title{
Chikungunya Virus Antibody Measurement
}

National Cancer Institute

\section{Source}

National Cancer Institute. Chikungunya Virus Antibody Measurement. NCI Thesaurus.

Code C135404.

The determination of the amount of the Chikungunya virus antibodies in a biological sample. 